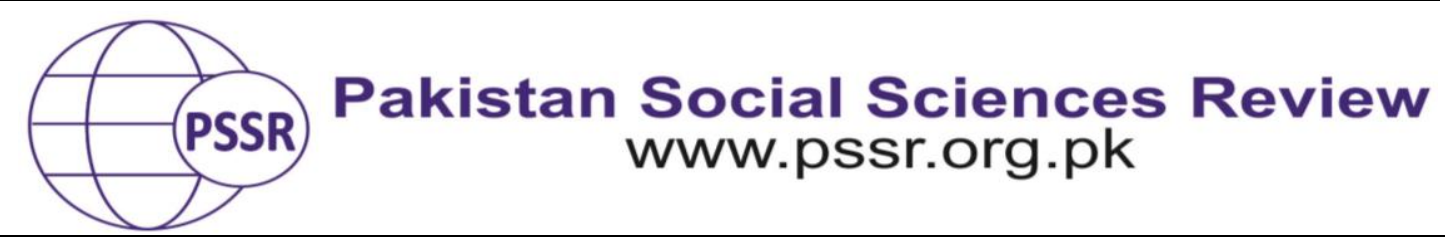

RESEARCH PAPER

\title{
Portrayal of Pakistan's Image in International Press Regarding Operation Zarb E Azab
}

\author{
Syed Ali Hassan Shahํํㄹ Dr Farish Ullah Yousafzai ${ }^{2}$
}

1. Ph. D Scholar, Centre for Media and Communication Studies, University of Gujrat, Hafiz Hayat Campus, Gujrat, Punjab, Pakistan

2. Professor, Centre for Media and Communication Dean of Arts, University of Gujrat, Hafiz Hayat Campus, Gujrat, Punjab, Pakistan

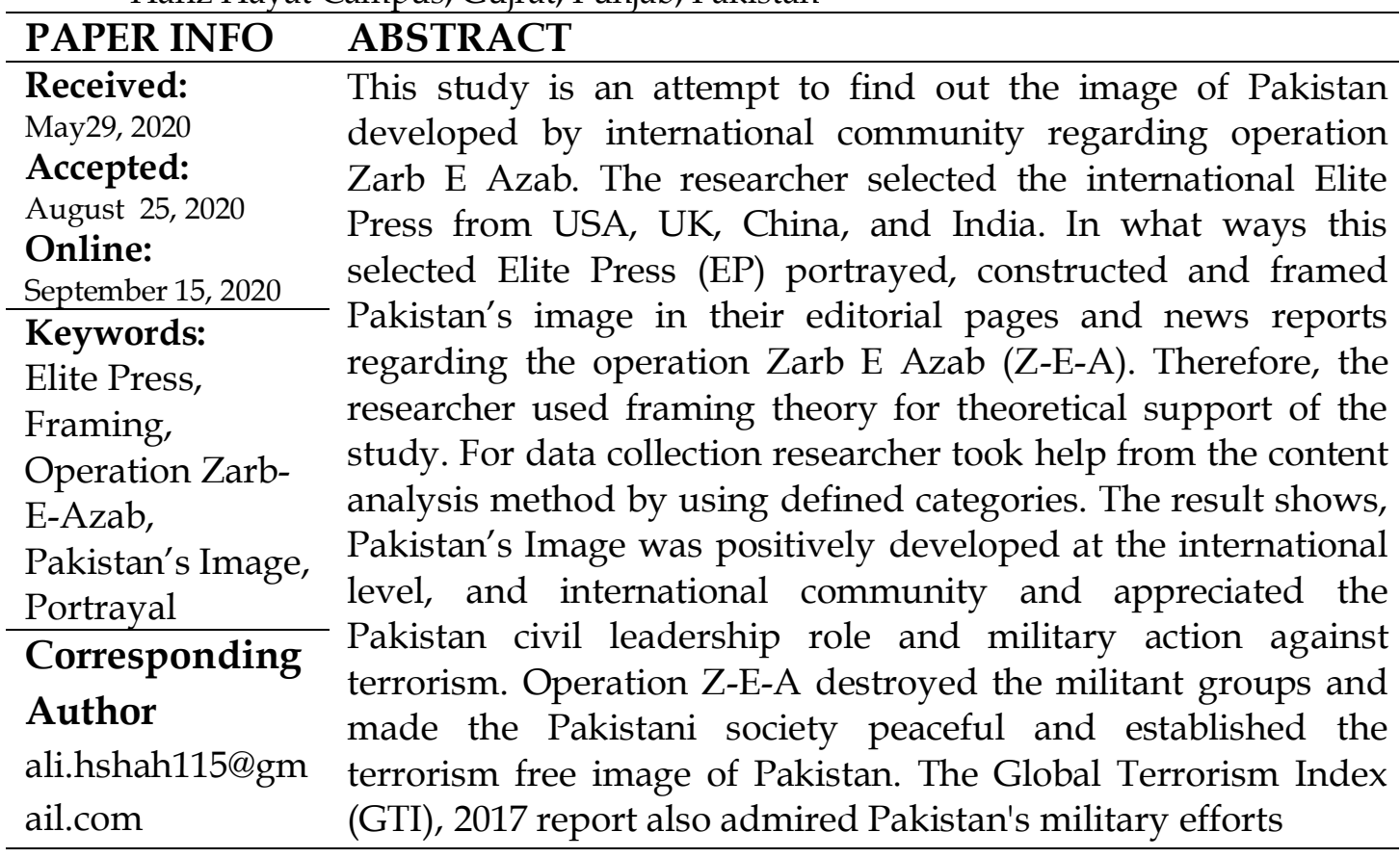

\section{Introduction}

Pakistan is situated in very significant geopolitical areas. Before this operation in Pakistan, terrorism activities were on the peak; daily news was full of bomb blasting, target killing, suicide attacks, etc. on the press front page and electronic media headlines. A terrible impression of Pakistan was going throughout the world. Media is the most vital instrument to speak to any individual, society, network, and region pictures. Media assumed the watchdog role and recorded every event that occurs in any place in the world. When Operation Z-E-A was launched against the self-slaughter, bomb blasting, shooting, mortalities by brutality, and extremist attacks in Pakistan, Pakistani media portrayed and framed the operation positively in the country as communicated throughout the world. This research determines. The researcher finds out how the selected International 
press portrayed the operation Z-E-A and Pakistan's image in editorial page stories and news.

\section{Operation Zarb-E-Azab (2014-2016)}

Zarb E Azab (Z-E-A) is an armed campaign launched by Pak Army repudiating different sorts of militants groups, such as Tahrika Taliban Pakistan (TTP), Al Quaida (A-Q) and all other lowlife attacker prepares on the brutal scene of the world with velour. The campaign is identified with "Z-E-A," imparted as an "exhaustive activity" for absolutely pounding abroad and ordinary radicals that are camouflaged in North Waziristan (NW). With the federal government's full help, the Pakistani army launched a terrible military offensive at the Z-E-A level in midJune 2014, energetically demanding the removal of terrible seedlings in North Waziristan Agency (NWA), which is a targeted base camp in FATA near Afghanistan. This effort is called Z-E-A' suggests that one of the seven swords of the Holy Prophet (PBUH), which was donated in Ghazwaz, Uhad, and Badr, struck hardened non-believers. Z-E-A signifies an "energetic and decisive strike" not over yet. Self-destruction bombings, target executing, fatalities by mercilessness, and dread monger ambush assaults had tormented the tranquility of Pakistan for a long time. In Pakistan, the vicinity of mental aggressor social gatherings in NWA was an essential reason behind most exceedingly awful fear-based oppressor ambushes in the most recent couple of years. (Ghazanfar, 2016)

In current circumstances, media, particularly the press, has expanded vision and capacity rather instructs illuminate, and engage. The primary focal point of research is to analyze the portrayal of Pakistan's image in the selected international E.P. of, USA, U.K., China, and India. In what ways this selected E.P. portrayed, constructed and framed Pakistan's image in their editorial page stories as well as in news stories regarding before and during the operation Z-E-A. Media outlets are entering player in building the picture of a specific nation and relying on their validity among the majority (Iqbal, 2012). In the present era, the press additionally performs numerous capacities like to portray, assess, manage, and scrutinize investigation considerably more evolving, reshaping, and controlling the general conclusions.

\section{Hypotheses of the Study}

H1 USA press portrayed the Negative image of Pakistan before operation Z-E-A USA press portrayed the positive image of Pakistan during operation Z-E-A

H2 UK press portrayed the Negative image of Pakistan before operation Z-E-A UK press portrayed the positive image of Pakistan during operation Z-E-A

H3 Chinese press portrayed the Negative image of Pakistan before operation Z-EA

Chinese press portrayed the positive image of Pakistan during operation Z-E-A 
H4 Indian press portrayed the Negative image of Pakistan before operation Z-E-A Indian press portrayed the positive image of Pakistan during operation Z-E-A

\section{Literature Review}

The examination article discussed the role of Pakistan military powers for the re-foundation of the writ of state after activity Z-E-A in FATA. Hamza (2017) led investigate in, for example, Parachinar, Miran Shah, Wana, Kalaya, and Khaar of FATA, the center regions of the fear-based oppressors. Information was gathered from 120 people from this examination inside 03 months from November 2016 to January 2017 on consistently. Military undertaking Z-E-A showed its condition and worked for the progression of that region. Suicide shells on military powers and dread based oppressor practices were significantly reduced after this action. While investigating it, it was found that joblessness is a significant explanation behind mental fighting in FATA, and besides, they are inflexible with their neighborhood or Pushtoon culture. Pak-Army concentrated on these mental aggressors, and some of them were caught from different associations of FATA, and some of them escaped to Afghanistan. There are purposes behind dread based mistreatment just as some outside workplaces drew in with this activity. As a result of dread mongering, Pakistan has been wrecked its legitimacy worldwide; they thought of it as the state of mental oppressors. Besides, Javed (2017) conferred; Fear-mongering is unquestionably not another marvel in the 21st century. It is as old as human intuition wants to expand the most excessive force on harmony and security. Since $9 / 11$, Islamabad has been going up against horrendous and protracts exhibitions of brutality, obsession, grabbing, target murdering, and impacts.

The above-said factors transformed inspiration into declining the harmony and security of the country. There are various ways to deal with taking out the primary drivers of dread mongering from the game plan of military exercises. Pakistan has characterized a counter dread based persecution standard from 20022008. Earlier General Ashfaq Pervez Kiyani (retired) started this show and created a framework to stop the mental oppressor's progressive practices through political game plans, agreements, directions, and the last hotel as a military task. The military tasks associated with the beheading of soldiers, Pakistan 9/11 (APS), the attack of Char Sadh College, are still ongoing. Therefore, it is difficult to assess the execution of Z-E-A, led by the departure of General Raheel Sharif, as jargon for the Z-E-A task. The Z-E-A task's goal has still not been achieved because there is a lack of trust between the military, ordinary Pakistani governments, in the United States, and Afghanistan. Steps must be taken to maintain harmony and reasonableness in this area. Research led to Detecting Grounds of Terrorism in Pakistan by Haider et al. (2015). They bring up that the fundamental objective of this examination is to explore the private likewise, general explanations behind dread based persecution, especially to Pakistan. 
Given that the country is a loss of no matter how the people look at its mental oppressor works out, an examination concerning the purposes behind dread mongering is required. Through and through gatherings and substance assessments have been used to examine the beginning explanations behind mental fighting considering the eventual outcomes of substance examination, a quantitative assessment prompted accumulate rank request data from the masters.

The results show that the most imperative reasons behind mental mistreatment consolidate the nonappearance of law approval, dejection, and Pakistan's participation in the war on fear, remote incorporation, and joblessness. This investigation gathers that no reason has an uneven relationship with mental mistreatment, and fixating on a single factor may not propose groundbreaking game plan measures. This investigation proposes a multifaceted a progressively connected with definite into the staggering purposes behind dread based mistreatment in Pakistan. Further included Pakistan's Security Situation after Operation Z-E-A by Zulfqar (2015) an overview of the security situation before and after Operation Z-E-A shows that Pakistan's security situation has gained much ground. The study highlights the success of the operation and sees future challenges, e.g., changing the political status of the FATA, ensuring the financial security of their families, launching more programs of de-radicalization and an incredible organization of Pakistan's periphery, which should generally be based on the principle of necessity. The document presumes that the beginning of the changes in FATA and the introduction of the innovative administration of the periphery in 2013 may change the area from being a security risk to a monetary quality in the country and its neighboring districts as well.

After the completion of Operation Z-E-A, the security situation in Pakistan has improved decently, and a graph of ambushes by mental oppressors shows that fear-based oppressors have been eminent targets of hard attack. Errand Z-E-A has adequately wrecked mental oppressor arranges in N.W., yet the supportability and robustness of its success depend upon the future approach. Like this, to cement and hold the increments of past military assignments, Operation Rad Ul Fasaad (February 2017) has been pushed over the country89 went from slaughtering the leftover/dormant danger of psychological oppression from the country. Also, Khan (2018) examined the connection between the confining of Z-E A activity in the dailies of Pakistan and the general supposition on the activity. It is a substantial investigation of four Pakistan driving papers, two English (Dawn and The News), and two Urdu papers (Nawa-I-Waqt and Daily Express). There is a connection between how media surrounded the activity Serbia as a positive development with the help of the administration and how individuals saw the issue.

Discoveries show that there is a positive and reliable connection between paper motivation and open plan on this national issue (Z-E-A activity) of Pakistan. The outcomes affirm the hypothetical agenda-setting conflict that there is a connection between the degree of consideration given to a specific issue in the media and the degree of essentialness doled out to that issue. The discoveries of the 
exploration study are likewise following the contentions of a few different specialists (Canel et al., 1996; Onyebadi, 2008) who found a stable connection between media motivation and open plan. The media inclusion of activity Z-E-A demonstrates that household media has given indications of reliability, feeling of nationalism, and proclivity to help hostile to fear battle. As psychological militants represent a genuine danger to Pakistan's inward security, in this way, all sections of society, including media, ultimately bolster the administration's choice to dispense with the fear mongers.

To summarize, this examination study infers a positive and stable connection among media and an open plan on a national issue (Z-E-A activity) in Pakistan. Also, Khan and Akhtar (2016) directed research on the Z-E-A process as far as media inclusion investigation. The substance investigation of Dawn, The News, and The Nation news during the Z-E-A process from June 15, 2014, to June 30, 2014, was dissected. The investigation of three original papers in Pakistan: Dawn, The News, and The Nation to cover the fourteen days of Z-E-A since its dispatch mirrors the negative setting of its inclusion. By concentrating on the procedure's negative system, it was seen that the leaves were not happy with the dispatch of the procedure. In their paper, Khalid and Roy (2016) look at the development, possibilities, and ramifications of Pakistan's counterterrorism endeavors and dissect the inefficacy of Pakistan's counter-psychological oppression approaches the period 2001-2013. Pakistan has been the most noticeably awful psychological militant hit state in the post 9/11 condition, which forfeits more than 8500 militaries, and right around 40000 non-military personnel lives.

Pakistan has continued to lose $\$ 45$ billion in total due to the military exercises conducted between September 2001 and 2009 and has investigated $\$ 70$ billion, including a massive number of customs and military lives up to the 2012 target line. In the vicinity, Pakistan also faced financial difficulties, as trade and the travel industry faced security challenges.

The GTI (2016) report tended to Military activities concurred with a decrease in fear-mongering in Pakistan. The Pakistan Armed forces began Operation Z-E-A in mid2014 focused on the N.W. district of the Federally Administered Tribal Areas, a locale was known as a position of shelter for activists. This has fundamentally influenced the Tehrik-I Taliban, with military specialists itemizing that in excess of 3,000 people were killed and that people had fled into Afghanistan to join the conflict there. The affiliation is moreover experiencing infighting over movement since the death of its pioneer Hakimullah Mehsud by a machine strike in November 2013. In 2015 the social occasion was subject to 36 percent of passing's, totaling 240 people. This is down from 59 percent of passings, totaling 544, in 2014 addressing a sharp year-on-year decline

Researcher used framing theory for theoretical support. Framing is an extension of the agenda setting theory. The idea of framing is an integral part of the second degree of priority-setting theory (Ghanem, 1997; Takeshita, 1997, mentioned 
in Miller's, 2001). The term "framing" refers to the input methods that writers and various communicators use to introduce data in a way that resonates with existing basic patterns in their crowds (Shoemaker and Reese, 1996). Framing can be described as a method in which various parts of an event are chosen and gradually given significant emphasis or criticism to show the problem, its causes, suggested moral choices, and reasonable ways of acting and exercising (Entman, 1993).

\section{Framing Theory}

Researcher used framing theory for theoretical support. The theory of the "framing study" is shown by Goffman (1974), which provides a useful record of how we use the desire to understand customary conditions that exist overnight and everything in them (Baran and Davis, 2003). Social experience consists of plans presented as models of affiliation that guide the enthusiastic consequences we direct to events (Goffman, 1974). Gitlin (1980) noted framing is "a persistent case of recognition, understanding, and presentation of affirmation, emphasis, and dismissal by which image professionals routinely organize the discussion, both verbally and visually." Herman (2000) defines state media threads as having the power to treat each event's photograph in a new norm and standard. Reese (2001) explains that the framing is based on models that 'intrigue, communicator, sources and culture,' in particular the wires, to give a coherent picture of events and issues through all verbal and non-verbal open methods. He says that "the framework is sifted through guidelines which, after a certain time, are socially divided and energetic, symbolically order the social world." (1) Organization: media messages are created mentally and culturally by the environment. (2) Principles: the charts fill in such reference points that they sift through all information related to a specific event so that they can leave an average impact on the group. (3) Shared: "The edge must participate in such a way that it is necessary and transferable." (4) Persistent: parcels suffer and are used by producers for a certain period for a specific issue. (5) Symbolic: lines act symbolically in different media content. (6) Structure: schemes can create reality. Generally speaking, structuring is beneficial for messages that give specific criticism to buyers on a given topic. At this point, plots can build a picture of the pioneers of individuals' social issues according to the different, multilevel views of the media.

\section{Materials and Methods}

Researcher utilized the quantitative approach in which used content analysis as method for data collection from selected International elite press. The elite press for this study took from the press of selected countries because they circulated widely nationwide and across the country. These are New York Times (NYT), The Sun, Global Times (G.T), and The Times of India (TOI). The analysis interval of this study is from January 1st, 2012, to December 31st, 2016. January 1st, 2012 to June 14th, 2014 (Before Operation Z-E-A Period) and June 15th, 2014 to December 31st, 2016 (During Operation Z-E-A Period). During this period, all 
editorial page stories and all news are analyzed on defined categories of the selected international press.

In this study, the unit of analysis is all the contents of editorial page stories and news regarding the selected issues is analyzed by the researcher in selected elite press (EP). The unit of analysis designates the closeness of 1) Terrorism Control 3) Success level of Military Operations and 3) Improvement in International Relation in the selected International E.P. The researcher measured the defined categories' on three categorical directions which are ranked as Positive (+1), Neutral (0) and Negative (-1)

Results and Discussion

Before Operation Z-E-A (1 ${ }^{\text {st }}$ January 2012 to $14^{\text {th }}$ June 2014)

Terrorism Control

\begin{tabular}{|c|c|c|c|c|c|c|c|}
\hline \multicolumn{4}{|c|}{ Terrorism Control } & \multicolumn{3}{|c|}{ Selected EP } & \multirow[b]{2}{*}{ Total } \\
\hline & & & & $\begin{array}{l}\text { NYT } \\
\text { (USA) }\end{array}$ & $\begin{array}{c}\text { G.T } \\
\text { (China) }\end{array}$ & $\begin{array}{c}\text { TOI } \\
\text { (India) }\end{array}$ & \\
\hline \multirow{6}{*}{ Positive } & \multirow{4}{*}{$\begin{array}{l}\text { Unit of } \\
\text { Analysis }\end{array}$} & Editorial & Count & & 1 & & 1 \\
\hline & & Page & $\%$ of Total & & $11.1 \%$ & & $11.1 \%$ \\
\hline & & \multirow{2}{*}{ News } & Count & & 8 & & 8 \\
\hline & & & $\%$ of Total & & $88.9 \%$ & & $88.9 \%$ \\
\hline & \multirow{2}{*}{\multicolumn{2}{|c|}{ Total }} & Count & & 9 & & 9 \\
\hline & & & $\%$ of Total & & $100.0 \%$ & & $100.0 \%$ \\
\hline \multirow{4}{*}{ Negative } & \multirow{2}{*}{$\begin{array}{c}\text { Unit of } \\
\text { Analysis }\end{array}$} & \multirow{2}{*}{ News } & Count & 21 & & 10 & 31 \\
\hline & & & $\%$ of Total & $67.7 \%$ & & $32.3 \%$ & $100.0 \%$ \\
\hline & \multirow{2}{*}{\multicolumn{2}{|c|}{ Total }} & Count & 21 & & 10 & 31 \\
\hline & & & $\%$ of Total & $67.7 \%$ & & $32.3 \%$ & $100.0 \%$ \\
\hline
\end{tabular}

Table indicates that there was 1 editorial published in G.T (China) in which portrayed terrorism controlled in Pakistan, also 8 news published in the same press in favor of terrorism controlled before the operation Zarb E Azab. Meanwhile, in the NYT (USA) and TOI Published news stories 21 and 10 respectively in which depicted that terrorism is not controlled in Pakistan before the Operation Z-E-A.

Success Level of Military Operation

\begin{tabular}{|c|c|c|c|c|c|c|c|}
\hline \multicolumn{4}{|c|}{ Success Level of Military Operation } & \multicolumn{3}{|c|}{ Selected EP } & \multirow[b]{2}{*}{ Total } \\
\hline & & & & $\begin{array}{l}\text { NYT } \\
\text { (USA) }\end{array}$ & $\begin{array}{c}\text { G.T } \\
\text { (China) }\end{array}$ & $\begin{array}{c}\text { TOI } \\
\text { (India) }\end{array}$ & \\
\hline \multirow{6}{*}{ Positive } & \multirow{4}{*}{$\begin{array}{c}\text { Unit of } \\
\text { Analysis }\end{array}$} & Editorial & Count & & 1 & & 1 \\
\hline & & Page & $\%$ of Total & & $11.1 \%$ & & $11.1 \%$ \\
\hline & & \multirow{2}{*}{ News } & Count & & 8 & & 8 \\
\hline & & & $\%$ of Total & & $88.9 \%$ & & $88.9 \%$ \\
\hline & \multirow{2}{*}{\multicolumn{2}{|c|}{ Total }} & Count & & 9 & & 9 \\
\hline & & & $\%$ of Total & & $100.0 \%$ & & $100.0 \%$ \\
\hline Negative & Unit of & News & Count & 21 & & 10 & 31 \\
\hline
\end{tabular}




\begin{tabular}{ccccc}
\hline Analysis & \% of Total & $67.7 \%$ & $32.3 \%$ & $100.0 \%$ \\
\hline \multirow{2}{*}{ Total } & Count & 21 & 10 & 31 \\
\cline { 2 - 5 } & \% of Total & $67.7 \%$ & $32.3 \%$ & $100.0 \%$ \\
\hline
\end{tabular}

Table reveals that 21 news stories published in the NYT (USA) and 10 news stories published in the TOI (India). Both press news stories disclosed that Pakistan's military did not take any action against militants before operation Z-E-A. However, 1 editorial page story and 8 news stories published in G.T (China) which disclosed Pakistan military took action against militants before the operation Z-E-A.

Improvement in International Relation

\begin{tabular}{|c|c|c|c|c|c|c|c|}
\hline & & & & \multicolumn{3}{|c|}{ Selected EP } & \multirow[b]{2}{*}{ Total } \\
\hline & & & & $\begin{array}{c}\text { NYT } \\
\text { (USA) }\end{array}$ & $\begin{array}{c}\text { G.T } \\
\text { (China) }\end{array}$ & $\begin{array}{c}\text { TOI } \\
\text { (India) }\end{array}$ & \\
\hline \multirow{6}{*}{ Positive } & \multirow{4}{*}{$\begin{array}{c}\text { Unit of } \\
\text { Analysis }\end{array}$} & \multirow{2}{*}{$\begin{array}{c}\text { Editorial } \\
\text { Page }\end{array}$} & Count & 0 & 1 & & 1 \\
\hline & & & $\%$ of Total & $.0 \%$ & $14.3 \%$ & & $14.3 \%$ \\
\hline & & \multirow{2}{*}{ News } & Count & 1 & 5 & & 6 \\
\hline & & & $\%$ of Total & $14.3 \%$ & $71.4 \%$ & & $85.7 \%$ \\
\hline & \multirow{2}{*}{\multicolumn{2}{|c|}{ Total }} & Count & 1 & 6 & & 7 \\
\hline & & & $\%$ of Total & $14.3 \%$ & $85.7 \%$ & & $100.0 \%$ \\
\hline \multirow{4}{*}{ Neutral } & \multirow{2}{*}{$\begin{array}{c}\text { Unit of } \\
\text { Analysis }\end{array}$} & \multirow{2}{*}{ News } & Count & & 2 & & 2 \\
\hline & & & $\%$ of Total & & $100.0 \%$ & & $100.0 \%$ \\
\hline & \multirow{2}{*}{\multicolumn{2}{|c|}{ Total }} & Count & & 2 & & 2 \\
\hline & & & $\%$ of Total & & $100.0 \%$ & & $100.0 \%$ \\
\hline \multirow{4}{*}{ Negative } & \multirow{2}{*}{$\begin{array}{c}\text { Unit of } \\
\text { Analysis }\end{array}$} & \multirow{2}{*}{ News } & Count & 10 & 1 & 5 & 16 \\
\hline & & & $\%$ of Total & $62.5 \%$ & $6.2 \%$ & $31.2 \%$ & $100.0 \%$ \\
\hline & \multirow{2}{*}{\multicolumn{2}{|c|}{ Total }} & Count & 10 & 1 & 5 & 16 \\
\hline & & & $\%$ of Total & $62.5 \%$ & $6.2 \%$ & $31.2 \%$ & $100.0 \%$ \\
\hline
\end{tabular}

Table enlightens that 10 news stories published in the NYT (USA), 5 news stories published in TOI (India), and 1 news story published in G.T (China). These news stories indicated that Pakistan's international relations did not improve with other countries before operation Z-E-A. However, 2 news stories published in G.T (China) which adopted a neutral stance regarding Pakistan international relation improvement with other countries before operation Z-E-A. While 1 editorial page story and 5 news stories published in G.T (China) and also 1 news story published in the NYT (USA). These stories addressed that Pakistan's international relations improved with other countries before operation Z-E-A. 
During Operation Z-E-A (15 ${ }^{\text {th }}$ June 2014 to $31^{\text {st }}$ December 2016)

Terrorism Control

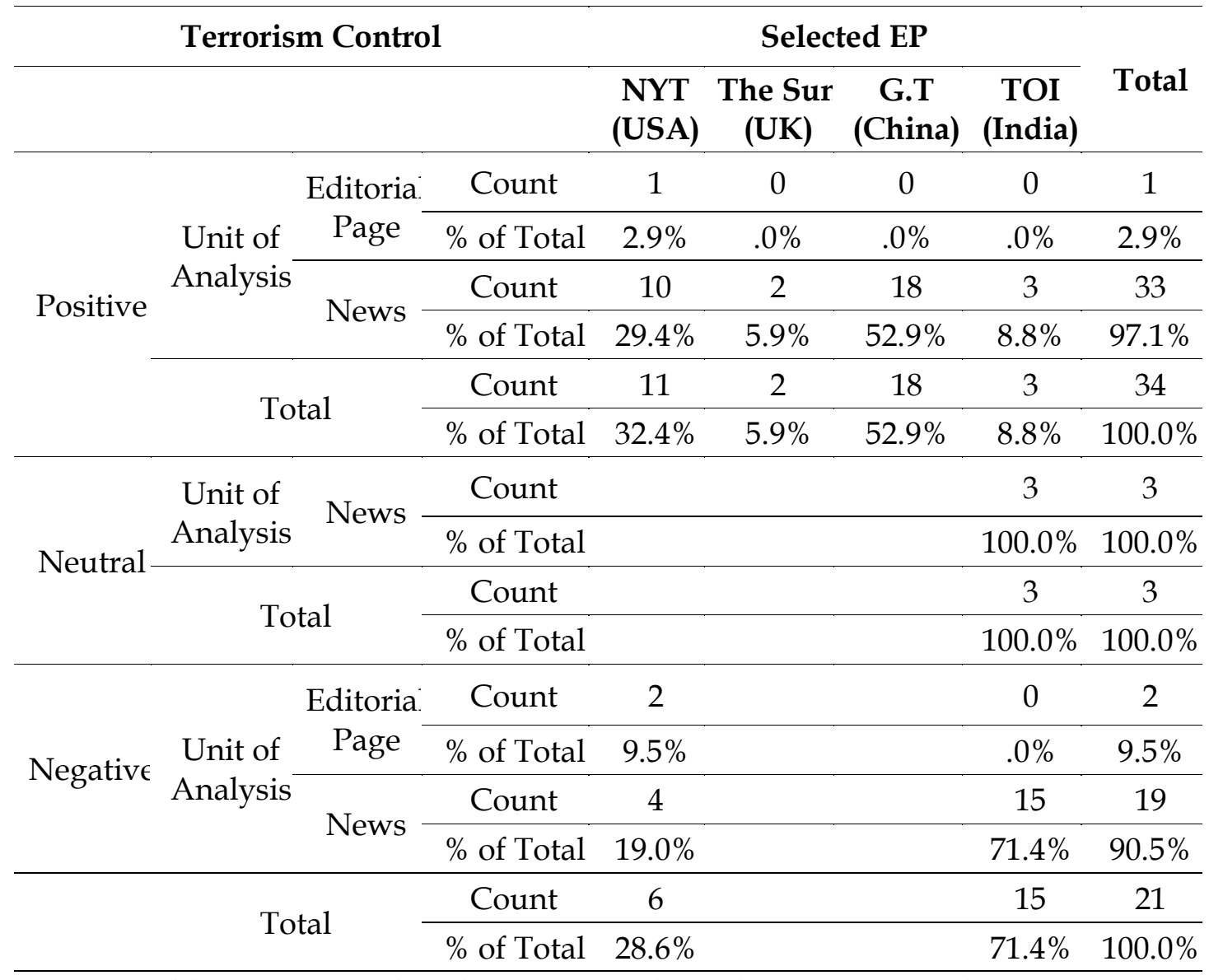

Table points out that there was 1 editorial page story and 10 news stories published in the NYT (USA), addressed the terrorism controlled in Pakistan during Operation Z-E-A. In the same time period, 2 editorial page stories and 4 news stories in the same press published that talked about terrorism is not controlled in Pakistan during operation Z-E-A. 18 news stories published in G.T (China) in which Portrayed Terrorism controlled in Pakistan, Though 15 news published in TOI (India) in which presented terrorism is not controlled in Pakistan during the Operation Z-E-A campaign. However, 2 news stories published in the Sun (UK) in favor of terrorism controlled in Pakistan during Operation Z-E-A. 


\section{Success Level of Military Operation}

\begin{tabular}{|c|c|c|c|c|c|c|c|c|}
\hline \multicolumn{4}{|c|}{ Success Level of Military Operation } & \multicolumn{4}{|c|}{ Selected EP } & \multirow[b]{2}{*}{ Total } \\
\hline & & & & $\begin{array}{c}\text { NYT } \\
\text { (USA) }\end{array}$ & $\begin{array}{c}\text { The Sur } \\
\text { (UK) }\end{array}$ & $\begin{array}{c}\text { G.T } \\
\text { (China) }\end{array}$ & $\begin{array}{c}\text { TOI } \\
\text { (India) }\end{array}$ & \\
\hline \multirow{6}{*}{ Positive } & \multirow{4}{*}{$\begin{array}{c}\text { Unit of } \\
\text { Analysis }\end{array}$} & \multirow{2}{*}{$\begin{array}{c}\text { Editorial } \\
\text { Page }\end{array}$} & Count & 1 & 0 & 0 & 0 & 1 \\
\hline & & & $\%$ of Total & $2.9 \%$ & $.0 \%$ & $.0 \%$ & $.0 \%$ & $2.9 \%$ \\
\hline & & \multirow{2}{*}{ News } & Count & 10 & 2 & 18 & 3 & 33 \\
\hline & & & $\%$ of Total & $29.4 \%$ & $5.9 \%$ & $52.9 \%$ & $8.8 \%$ & $97.1 \%$ \\
\hline & \multirow{2}{*}{\multicolumn{2}{|c|}{ Total }} & Count & 11 & 2 & 18 & 3 & 34 \\
\hline & & & $\%$ of Total & $32.4 \%$ & $5.9 \%$ & $52.9 \%$ & $8.8 \%$ & $100.0 \%$ \\
\hline \multirow{4}{*}{ Neutral -} & \multirow{2}{*}{$\begin{array}{l}\text { Unit of } \\
\text { Analysis }\end{array}$} & \multirow{2}{*}{ News } & Count & & & & 1 & 1 \\
\hline & & & $\%$ of Total & & & & $100.0 \%$ & $100.0 \%$ \\
\hline & \multirow{2}{*}{\multicolumn{2}{|c|}{ Total }} & Count & & & & 1 & 1 \\
\hline & & & $\%$ of Total & & & & $100.0 \%$ & $100.0 \%$ \\
\hline \multirow{6}{*}{ Negative } & \multirow{4}{*}{$\begin{array}{c}\text { Unit of } \\
\text { Analysis }\end{array}$} & \multirow{2}{*}{$\begin{array}{c}\text { Editorial } \\
\text { Page }\end{array}$} & Count & 2 & & & 0 & 2 \\
\hline & & & $\%$ of Total & $8.7 \%$ & & & $.0 \%$ & $8.7 \%$ \\
\hline & & \multirow{2}{*}{ News } & Count & 4 & & & 17 & 21 \\
\hline & & & $\%$ of Total & $17.4 \%$ & & & $73.9 \%$ & $91.3 \%$ \\
\hline & \multirow{2}{*}{\multicolumn{2}{|c|}{ Total }} & Count & 6 & & & 17 & 23 \\
\hline & & & $\%$ of Total & $26.1 \%$ & & & $73.9 \%$ & $100.0 \%$ \\
\hline
\end{tabular}

Table shows that 1 editorial page story and 11 news stories published in the NYT (USA), briefs that which disclosed Pakistan military successfully, smash militants during the operation Z-E-A. At the same time 18, 3, and 2 news stories published in G.T (China), TOI (India), and The Sun (UK) respectively. These press accepted that Pakistan's military successfully hit militants during the operation Z-EA. However, 2 editorial page stories and 4 news stories published in the NYT (USA) and 17 news stories published in TOI (India). Both press news stories also disclosed that the Pakistan military failed against militants during operation Z-E-A.

\section{Improvement in International Relation}

\begin{tabular}{|c|c|c|c|c|c|c|c|}
\hline & & & & \multicolumn{3}{|c|}{ Selected EP } & \multirow[b]{2}{*}{ Total } \\
\hline & & & & $\begin{array}{l}\text { NYT } \\
\text { (USA) }\end{array}$ & $\begin{array}{c}\text { G.T } \\
\text { (China) }\end{array}$ & $\begin{array}{c}\text { TOI } \\
\text { (India) }\end{array}$ & \\
\hline \multirow{4}{*}{ Positive } & \multirow{2}{*}{$\begin{array}{c}\text { Unit of } \\
\text { Analysis }\end{array}$} & \multirow{2}{*}{ News } & Count & 6 & 9 & 1 & 16 \\
\hline & & & $\%$ of Total & $37.5 \%$ & $56.2 \%$ & $6.2 \%$ & $100.0 \%$ \\
\hline & \multirow{2}{*}{\multicolumn{2}{|c|}{ Total }} & Count & 6 & 9 & 1 & 16 \\
\hline & & & $\%$ of Total & $37.5 \%$ & $56.2 \%$ & $6.2 \%$ & $100.0 \%$ \\
\hline
\end{tabular}




\begin{tabular}{|c|c|c|c|c|c|c|}
\hline \multirow{4}{*}{ Neutral } & \multirow{2}{*}{$\begin{array}{l}\text { Unit of } \\
\text { Analysis }\end{array}$} & \multirow{2}{*}{ News } & Count & \multicolumn{2}{|l|}{1} & 1 \\
\hline & & & $\%$ of Total & $100.0 \%$ & & $100.0 \%$ \\
\hline & \multirow{2}{*}{\multicolumn{2}{|c|}{ Total }} & Count & 1 & & 1 \\
\hline & & & $\%$ of Total & $100.0 \%$ & & $100.0 \%$ \\
\hline \multirow{4}{*}{ Negative } & \multirow{2}{*}{$\begin{array}{l}\text { Unit of } \\
\text { Analysis }\end{array}$} & \multirow{2}{*}{ News } & Count & 1 & 5 & 6 \\
\hline & & & $\%$ of Total & $16.7 \%$ & $83.3 \%$ & $100.0 \%$ \\
\hline & \multirow{2}{*}{\multicolumn{2}{|c|}{ Total }} & Count & 1 & 5 & 6 \\
\hline & & & $\%$ of Total & $16.7 \%$ & $83.3 \%$ & $100.0 \%$ \\
\hline
\end{tabular}

Table reflects that 9 news stories published in G.T (China), 6 news stories published in the NYT (USA), and 1 news story published in TOI (India). These news stories indicated that Pakistan's international relations improved with other countries before operation Z-E-A. However, 1 news stories published in G.T (China) which assumed the neutral standpoint regarding Pakistan's international relations improvement with other countries before operation Z-E-A. While 1 news story published in G.T (China) and 5 news stories published in TOI (India). These stories addressed that Pakistan's international relations did not improve with other countries before operation Z-E-A.

\section{Conclusion}

The study reveals that the Portrayal of Pakistan's Image in the international E.P. regarding Operation Z-E-A as hypothesizes approved the U.S.s America's press portrayal of Pakistan positively during Operation Z-E-A. The U.S. State Department country reports on terrorism, opened in June 2016, valued Pakistan's endeavors to control fear-based oppression, and kept up that Pakistan "stayed a basic counterterrorism accomplice in 2015." The report further recognizes the Operation Z-E-A and peruses, all through 2015, "the Pakistani military proceeded with the ground and air tasks in N.W. and Khyber Agency to kill terrorist their places of refuge and recoup illicit weapons reserves. G.T., Chinese press framed supportive and favorable Image of Pakistan at the international level before as well as during the Operation Z-E-A. Operation Z-E-A has complemented the beneficial outcome of Pakistan's security, dependability, and progress. The uber task of $\$ 42$ billion CPEC started after the right security circumstance in Pakistan. With overcoming fear based oppression, the Pakistan Forces have skilled the country with the harmony that ensures success under CPEC. (The Nation Report, 2016). Therefore, the Chinese press used to encourage and approaches to present Pakistan's Image as well as Pakistan force's efforts alongside militants globally.

The TOI highly criticized Pakistan's attitude towards terrorism not only before Operation Z-E-A started but also during the Operation. As the study approved, TOI presented Pakistan's Image contrary in their stories before and during this military Operation. In some stories, the TOI clearly stated Pakistan is terrorist safe heaven. Indian press portrayal negative Image of Pakistan, meanwhile, South Asian Terrorism Portal contradicted the TOI stance and acknowledged the 
Pakistan efforts against the terrorist groups. According to South Asian Terrorism Portal, in Pakistan, during 2013, fear-mongers did 43 assaults; nevertheless, during 2015,2016 , the number of suicide assaults plunged in the nation, and the credit went to the Operation Z-E-A. A diminished level of non-military personnel losses, from fear monger savagery (2014-2016) SATP till June 26th, 2016. It is concluded that Pakistan's Image was positively developed among the international community as a whole. USA security departments recognized and appreciated the Pakistan civil leadership role and military action against terrorism. Operation Z-EA demolished the militant groups and made Pakistani society peaceful as well as developed healthy foreign relations. As clearly mentioned in The GTI, 2015, it analyses the impact of terrorism on the global community. The report yielded the achievement of Z-E-A and expressed, "Pakistan was the main nation in the ten most affected nations that saw a decrease in passings and as needs are it dropped from third to fourth." Both reports of GTI 2013 and 2017, show that Pakistan has declined from 9.074. Where it was 2nd in the terrorism list in 2013 to 6.813 in 2017, where it dropped to the 13th point in a similar list, these reports statistically authenticate positive Image of Pakistan among the international community and establishing a healthy relationship with other countries also upgraded after the successful military Operation Z-E-A against terrorist groups. 


\section{References}

Baran, S. J., \& Davis, D.K .(2003). Mass communication theory: foundation, ferment, and future. Belmont: Wadsworth.

Canel, M., Llamas, J., \& Rey, F. (1996). The First-Level Agenda-Setting Effects on Local Information: The "Most Important Problems" of the City of Panama, Communication Y Sociedad, 9(1), 17

Entman, R. M. (1993). Framing: Toward Clarification of a Fractured Paradigm. Journal of Communication, 43(4), autumn.

Goffman, E. (1974). Frame analysis, NY: Harper Colophon

GTI (2013). Institute for Economics and Peace: Measuring and Understanding the Impact of Terrorism. Institute for Economics and Peace. Retrieved from www.economicsandpeace.org

GTI (2015). Institute for Economics and Peace: Measuring and Understanding the Impact of Terrorism. Institute for Economics and Peace. Retrieved from www.economicsandpeace.org

GTI (2016). Institute for Economics and Peace: Measuring and Understanding the Impact of Terrorism. Institute for Economics and Peace. Retrieved from www.economicsandpeace.org,

GTI (2017). Institute for Economics and Peace: Measuring and Understanding the Impact of Terrorism. Institute for Economics and Peace. Retrieved from www.economicsandpeace.org

Gitlin, T. (1980). The Whole World is Watching: Mass Media in the Making and the Unmaking of the New Left, Berkeley: University of California Press.

Ghazanfar, S. (2016). Operation Zarb-e-Azb: Two years of Success, The Nation Report, Published Sept 6, 2016 Retrieved https://nation.com.pk/06-Sep2016/operation-zarb-e-azb-two-years-of-success

Haider, S., De Pablos Heredero, C., Ahmed, M., \& Dustgeer, S. (2015). Identifying Causes of Terrorism in Pakistan. Dialogue (Pakistan), 10(3).

Hamza, H. (2017). Operation Zarb-e-Azb: A Success Story of Pakistan Military Forces in FATA, Al-Khair University, Azad Jammu \& Kashmir, Bhimber.

Herman, E. S. (2000). 'The Propaganda Model: A Retrospective', Journalism Studies, $1(1), 101-12$

Iqbal, Z. (2012). US Image in Pakistani Print Media: Framing Analysis of the Editorials of Dawn, The News and The Nation. 
Javed, A. (2017). Pakistan Counter Terrorism Policy since Zarb-i-Azab: Challenges and Prospects for Peace and Security. Journal of Politics and International Studies, 3(1).

Khan, A. (2018). Zarb-e-Azb Operation: Agenda Setting Role of Newspapers on a national Issue in Pakistan. Journal of Media Studies, 33(2).

Khan, S., \& Akhtar, N. (2016). Operation Zarb-e-Azb. Strategic Studies, 36(1), 114127.

Khalid, I., \& Roy, M. I. (2016). Pakistan's military operations: the counter terrorism strategy (2001-2013) prospects and implications. Journal of the Research Society of Pakistan, 53(2).

Miller, K. (2001). Communication Theories: Perspectives, Processes, and Contexts 1st Edition, Boston: McGraw Hill

Onyebadi, U. (2008). Towards an Examination and Expansion of the Agenda Setting : Did The Media Matter in Kenya's Presidental Election 2007?

Reese, S. (2001). Framing public life: A bridging model for media research. In S. Reese, O. Gandy, \& A. Grant(Eds.), Framing Public life (pp. 7-31). Mahwah, NJ: Erlbaum

Shoemaker, P., \& Reese, S. D. (1996). Mediating the Message, Theories of Influences on Mass Media Content, Longman, New York, NY.

South Asian Terrorism Portal. (2016). Retrieved From: https:/ / www.satp.org/terrorism-assessment

United States Department of State Publication. (2016). Counter Terrorism Report 2015. Bureau of Counterterrorism and Countering Violent Extremism, Released June 2, 2016

Zulfqar, S. (2015). An Overview of Pakistan's Security Situation after Operation Zarb-e-Azb. South Asian Studies. 30(2), 43-58. 